\title{
KOMUNIKASI UNTUK MENGASAH POTENSI ANAK (Pengabdian Kepada Masyarakat di RPTRA Mandala Tomang)
}

\author{
Eko Harry Susanto ${ }^{1}$ dan Rezi Erdiansyah ${ }^{2}$ \\ ${ }^{1,2}$ Fakultas Ilmu Komunikasi Universitas Tarumanagara Jakarta \\ Ekos@fikom.untar.ac.id, Rezie@fikom.untar.ac.id
}

\begin{abstract}
ABSTRAK
Mengasah potensi anak dalam berkomunikasi dengan menggunakan bahasa Inggris merupakah hal penting saat ini. Berdasarkan data Jakarta Open Data menunjukan masih banyak terdapat anak-anak yang tidak mendapatkan pendidikan, salah satunya di Jakarta Barat. Oleh sebab itu Fakultas Ilmu Komunikasi Universitas Tarumanagara berkesempatan memberikan pelatihan bahasa Inggris kepada anak-anak di lingkuanan Ruang Terbuka Ramah Anak (RPTRA) Mandala di Tomang Jakarta Barat. Metode pelaksanaan yang digunakan dalam kegiatan pengabdian kepada masyarakat ini adalah dengan observasi langsung untuk menjaring informasi kepada pengelola RPTRA terkait kebutuh apa yang diharapkan untuk mengisi kegiatan tersebut. Dari hasil diskusi tersebut pelatihan bahasa Inggris sangat dibutuhkan RPTRA saat ini. Sehubungan dengan hal tersebut Tim PKM Fikom Untar merancang kegiatan dengan bekerjasama dengan mahasiswa Fikom Untar. Hasilnya adalah anak-anak di lingkuang RPTRA dapat mengetahui dan menggunakan bahasa Inggris pada level mendasar, dan anak-anak mampu memupuk keberanian untuk berbicara dengan menggunakan bahasa Inggris.
\end{abstract}

Kata kunci: Komunikasi, Pengabdian Kepada Masyarakat

\section{PENDAHULUAN}

Perkembangan teknologi dewasa ini memberi dampak pada cara manusia berkomunikasi. Tidak hanya dalam kaitan jarak dan waktu, perkembangan teknologi komunikasi juga membawa perubahan di dalam bagaimana manusia berinteraksi dan membangun hubungan satu sama lain. Kedekatan seseorang dengan orang lain bukan saja dilihat secara fisik namun pada hubungan virtual yang dibangun melalui internet. Indonesia sebagai salah satu Negara berkembang mengalami pertumbuhan yang pesat dalam penggunaan internet. Menurut kompas.com Hasil penelitian Yahoo dan Taylor Nelson Sofres (TNS) menunjukkan bahwa pengakses internet terbesar di Indonesia adalah mereka yang berusia antara 15-19 tahun (Loisa \& Setyanto, 2014). Perkembang teknologi tersebut seharusnya didukung juga perkembangan sumber daya manusia. Khususnya disektor pendidikan. Pendidikan sampai saat ini dianggap sebagai unsur utama dalam pengembangan sumber daya manusia dan lebih bernilai jika memiliki sikap, perilaku, wawasan, kemampuan, keahlian serta keterampilan yang sesuai dengan kebutuhan berbagai bidang. Bangsabangsa maju di dunia ditopang oleh sumber daya manusia yang berkualitas, sehingga memiliki keunggulan hampir di semua bidang. Oleh karenanya, kemajuan suatu bangsa sangat ditentukan oleh kualitas pendidikan yang dimilikinya (Sari, 2018). Kesadaran bangsa Indonesia akan pentingnya pendidikan dituangkan dalam pembukaan UUD 1945 dengan pernyataan bahwa salah satu tujuan dibentuknya Negara Republik Indonesia adalah mencerdaskan kehidupan bangsa (Itu, dalam Sari, 2018).

Berdasarkan data yang dikeluarkan oleh pemerintah DKI Jakarta yang disebar melalui aplikasi Jakarta Open Data terlihat bahwa masih adalah anak-anak di Jakarta yang putus sekolah, Data tahun 2011-2014 baru yang dirilis pemerintah DKI Jakarta menunjukan bahwa Jakarta Barat menempati posisi tertinggi dengan anak-anak yang mengalami putus sekolah atau sebesar $40 \%$, dibandingkan dengan kotamadya yang lain seperti Jakarta Timur sebesar 25\%, Jakarta Selatan $20 \%$, Jakarta Utara $14 \%$, dan kepulauan Seribu $1 \%$. Berikut ini dalah diagram data putus sekolah DKI Jakarta. 


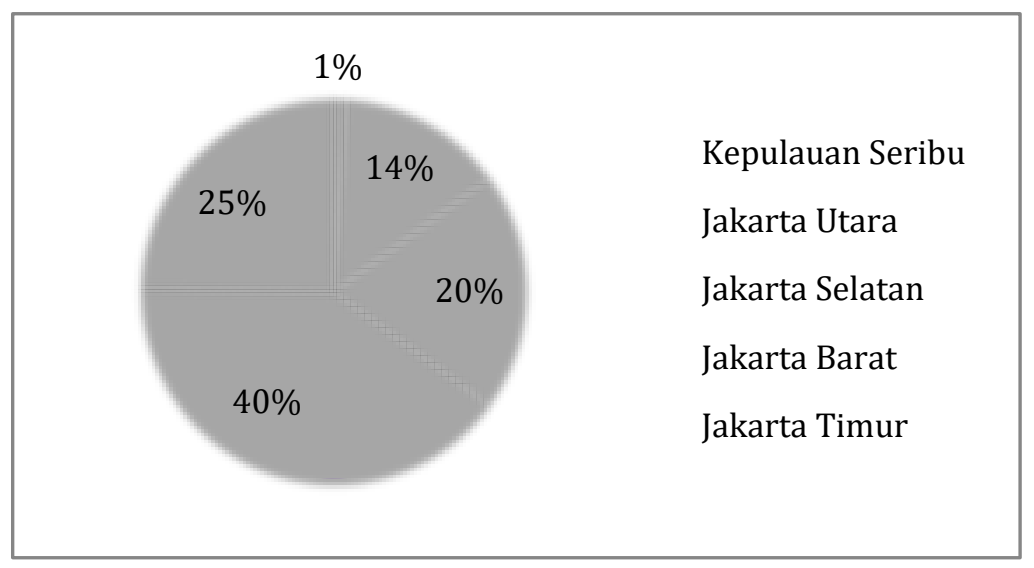

Gambar 1. Data Putus Sekolah DKI Jakarta

Sumber: http://data.jakarta.go.id/dataset/

Masalah putus sekolah secara tidak langsung memiliki dampak tersendiri dalam perkembangan anak-anak di wilayah tersebut. Hal tersebut ditunjukan dalam riset komunikasi terkait pengembangan RPTRA. Seperti penelitian terdahulu (Regi, 2016) dengan tema Analisis Framing Pemberitaan Penertiban Kawasan Prostitusi Kalijodo Menjadi Ruang Hijau Terbuka di Kompas.com menunjukan bahwa peliknya permasalah perubahan fungsi yang dilakukan Pemerintah Provinsi DKI Jakarta dalam menertibkan kawasan Kalijodo, menjadi kawasan ruang terbuka hijau yang dibingkai oleh kedua media tersebut. Serta masih ada riset komunikasi lain yang membahas tentang Ruang Terbuka Publik Terpadu Ramah Anak (RPTRA) MandalaTomang Mandala, baik dari segi fenomena sosial maupun kontek tekstual. Namun dari riset-riset yang membahas hal tersebut, belum terdapat kegiatan pengabdian kepada masyarakat ditempat tersebut yang mengasah potensi anak dengan bahasa Inggris. Sehubungan dengan hal tersebut masih peliknya permasalahan yang merundung anak-anak di kawasan RPTRA Tomang Mandala membawa keprihatinan bagi Fakultas Ilmu Komunikasi Universitas Tarumanagara. Oleh sebab itu Fikom Untar berupaya membantu pendidikan anak-anak khususnya diwilayah Jakarta Barat untuk Mengasah Potensi Anak-Anak Di RPTRA Tomang Mandala Dalam Berkomunikasi Dengan Menggunakan Bahasa Inggris. Kegiatan ini sejalan dengan RPJM DKI Jakarta dalam memberikan pendidikan wajib anak diusia dini.

\section{PERMASALAHAN MITRA}

Berdasarkan analisis situasi yang telah dijelaskan diatas, maka peneliti membuat sebuah uraian mengenai rumusan permasalahan yang dihadapi oleh mitra, yaitu sebagai berikut:

1) Tingginya angka putus sekolah di Jakarta Barat seperti yang digambarkan pada diagram 1 sebesar sebesar 40\%. RPTRA Tomang Mandala terletak di wilayah Jakarta Barat, menjadi tempat yang tepat untuk dilakukanya kegiatan PKM.

2) RPTRA Tomang Mandala menjadi wandah anak-anak DKI Jakarta khususnya Jakarta Barat untuk beraktivitas seperti bermain dan berinteraksi dengan anak-anak yang lain.

3) Ketidakstabilan politik di wilayah RPTRA Tomang Mandala yang dipaparkan dalam riset-riset terdahulu membuat wilayah tersebut semakin potensial untuk dijadikan tempat PKM, karena kompleksnya permasalah sosial yang muncul.

Berdasarkan permasalahan RPTRA Tomang Mandala diatas, maka Tim Pengabdian Kepada Masyarakat (PKM) Fakultas Ilmu Komunikasi Universitas Tarumanagara akan melakukan diskusi terhadap masyarakat setempat terkait masalah apa yang sebenarnya dihadapi. Hal tersebut akan dijadikan masukan untuk menemukan solusi yang tepat dari permasalahan tersebut. Kemudian, berdasarkan hasil pertimbangan atau justifikasi yang dibuat atas dasar diskusi 
bersama dengan mitra, peneliti memutuskan untuk mengadakan kegiatan Pengabdian Kepada Masyarakat dengan tema "Mengasah Potensi Anak-Anak Di RPTRA Tomang Mandala Dalam Berkomunikasi Dengan Menggunakan Bahasa Inggris"

\section{METODE PELAKSANAAN}

Metode pelaksanaan yang digunakan dalam kegiatan ini dapat dilihat dari table bagan berikut ini:

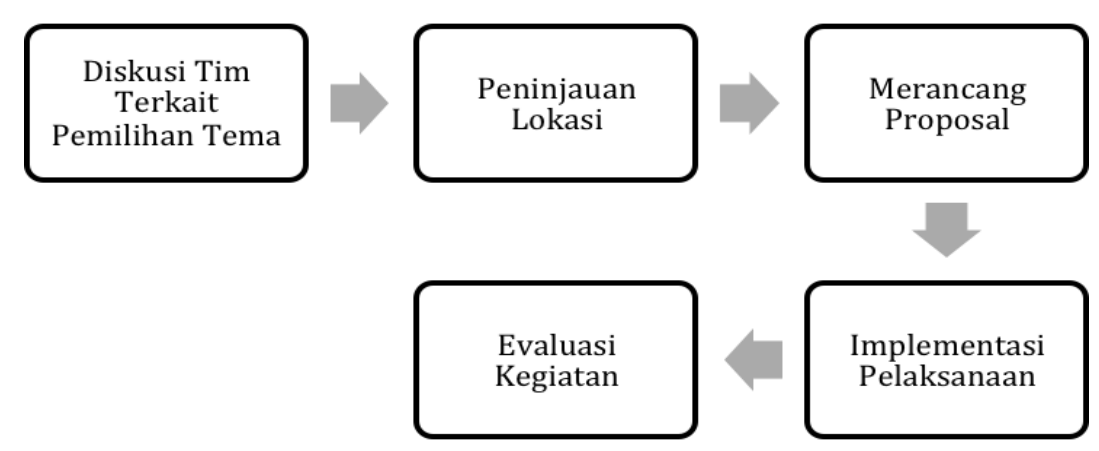

Gambar 2. Metode Pelaksanaan Kegiatan PKM

1) Pertama, tim kegiatan pengabdian kepada masyarakat FIKOM Untar melakukan diskusi terkait tema Mengasah Potensi Anak-Anak Di RPTRA Tomang Mandala Dalam Berkomunikasi Dengan Menggunakan Bahasa Inggris.

2) Kedua, tim kegiatan pengabdian kepada masyarakat FIKOM Untar akan meninjau suasana lingkungan sosial di RPTRA Tomang Mandala

3) Ketiga, merancang program penyuluhan yang tepat untuk terkait Mengasah Potensi AnakAnak RPTRA Tomang Mandala Dalam Berkomunikasi Dengan Menggunakan Bahasa Inggris.

4) Tahap implementasi pelaksanaan kegiatan PKM dapat dilakukan jika proposal sudah disetujui dan mendapat masukan dari DPPM UNTAR.

5) Evaluasi Kegiatan dilakukan untuk mengukur keberhasilan suatu program kegiatan PKM.

\section{HASIL DAN PEMBAHASAN}

Terletak $2 \mathrm{~km}$ dari Universitas Tarumanagara, RPTRA Tomang Mandala yang berdiri sejak 2017, mejadi wadah anak-anak DKI Jakarta untuk belajar dan bermain. RPTRA Tomang Mandala beralamat di RT.12/RW.4, Tomang, Jakarta Barat, saat ini memiliki beberapa fasilitas dan sistem pengelolaan yang baik. Fasilitas seperti ruang bermain, lapangan, papan tulis, dan lain-lain disediakan oleh pemerintah DKI Jakarta untuk membangun sauna yang kondusif untuk pertumbuhan anak-anak. Berikut ini adalah lokasi RPTRA Tomang Mandala dan suasana RPTRA Tomang Mandala.

Dalam melakukan kegiatan Pengabdian Kepada Masyarakat, Tim Pengabdian Kepada Masyarakat (PKM) Fakultas Ilmu Komunikasi Universitas Tarumanagara, melakukan korespondensi kepada pengelola RPTRA Mandala Ibu Fitri. Di dalam korespondensi tersebut Tim PKM Fikom untar menanyakan kebutuhan apa yang diperlukan untuk menunjang kegiatan di RPTRA Mandala. 
"Kami membutuhkan program-program untuk mengisi kegiatan di RPTRA, mungkin bisa pelatihan bahasa Inggris, karena kami kesulitan mengajar bahasa Inggris dan anak-anak RPTRA juga menanyakan ada bimbel bahasa Inggris ngak bu, selama ini baru ada kesenian dan olah raga. Namun yang bersifat bimbel belum ada, bagaimana Fikom Untar yang membantu kami untuk bimbel" Ujar Fitri

Atas dasar korespondensi tersebut, Tim PKM Fikom Untar merancang hal-hal yang perlu dipersiapkan dalam kegiatan tersebut. Dengan berkolaborasi dengan mahasiswa, Tim PKM Fikom Untar membuat perencanaan untuk kegiatan dan materi apa yang akan disampaikan dan sarana berupa buku gambar, buku tulis, alat tulis, pensil warna dan buku materi yang dibutuhkan untuk kegiatan tersebut.

Setelah perencanaan dan materi kegiatan sudah siap, Tim Fikom Untar bergegas untuk melakukan kegiatan Pengabdian Kepada Masyarakat di RPTRA Mandala. Sesampainya di RPTRA Mandala, Tim PKM Fikom Untar langsung memulai dua kegiatannya. Berikuti ini penjelasannya kegiatan PKM FIkom Untar.

Pertama, diawali dengan sesi percakapan dengan menggunakan bahasa inggris serta perkenalan mahasiswa Fikom Untar dengan anak-anak di RPTRA Mandala dengan menggunakan bahasa Inggris. Tujuan dari sesi pengenalan ini bertujuan untuk menumbuhkan rasa kedekatan antara mahasiswa dan anak-anak di RPTRA Mandala. Selain itu tujuan dari sesi perkenalan adalah untuk menumbuhkan rasa keberanian anak dalam berkomunikasi dengan menggunakan bahasa Inggris. Kemudian mahasiswa Fikom Untar mengajak anak- anak RPTRA Mandala untuk tampil kedepan satu per satu dan secara berkelompok berkomunikasi dengan menggunakan bahasa Inggris. Respon yang dimiliki anak-anak RPTRA Mandala sangat baik. Banyak diantara anakanak tersebut langsung maju kedepan untuk membaca kalimat bahasa Inggirs yanga ada di papan tulis yang Sehingga tim Fikom Untar tidak kesulitan untuk mengajak anak-anak berkomunikasi. Berikut ini adalah dokumentasi kegiatan tahap pertama:
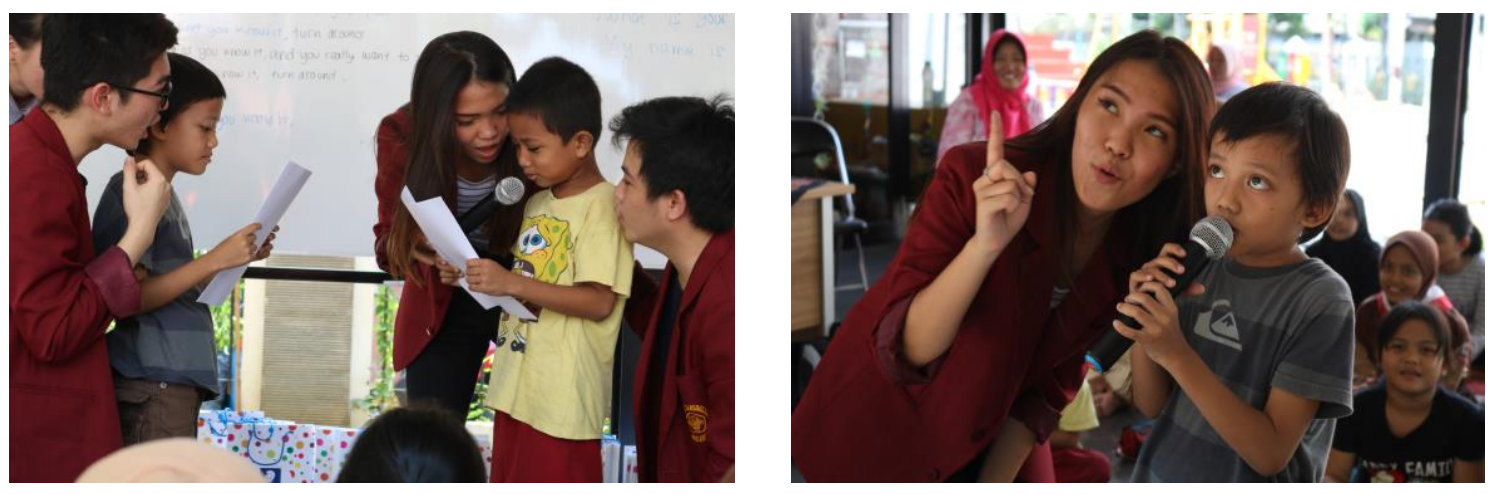

Gambar 3. Kegiatan Petama, Sesi Pecakapan dengan Menggunakan Bahasa Inggris (Sumber: data pribadi)

Kedua, setelah berkomunikasi dengan menggunakan bahasa Inggris, Tim PKM Fikom Untar mengajak anak-anak menuangkan kreatifitasnya dalam mewarnai. Tim PKM Fikom Untar membagiakan satu per satu alat tulis kepada seluruh anak-anak yang hadir di RPTRA Mandala. Setelah mendapatkan alat tulis tersebut anak-anak mulai menggambar sesuai dengan arahan mahasiswa Fikom Untar. Setelah mewarnai mahasiswa meminta anak-anak untuk mengumpulkan hasil mewarnainya untuk diberikan penilaian. Mahasiswa memilih mana saja gambar-gambar yang bagus untuk diberkan hadiah. Setelah melakukan koreksi mahasiswa 
memanggil satu per satu anak-anak di RPTRA Mandala yang memiliki hasil mewarnai terbaik untuk diberikan hadiah. Anak-anak terlihat senang dan sangat antusia atas kegiatan tersebut. Berikut ini adalah dokumentasi kegiatan kedua.
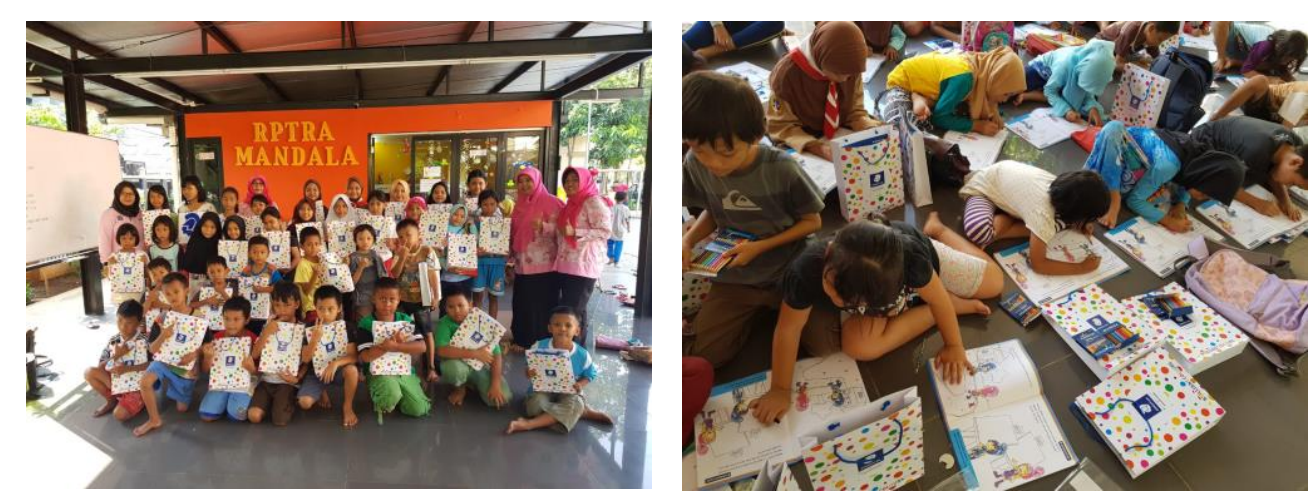

Gambar 4. Kegiatan Kedua, Sesi Mewarnai (Sumber: data pribadi)

Terakhir, kegiatan pengabdian kepada masyarakat ini ditutup dengan bernyanyi dan foto bersama. Kegiatan PKM di RPTRA Mandala bisa dibilang sukses. Indikator sukses bisa dilihat dari banyaknya peserta anak-anak Di RPTRA Mandala yang datang, kemudian antusiasme anakanak dalam kegiatan tersebut, dan pengelola RPTRA Mandala yang sangat aktif dan dengan senang hati menerima kedatangan Tim PKM Fikom Untar. Tidak hanya itu kesuksesan acara ini bisa dilihat dari media onlie yang mempublikasi kegiatan tersebut sepeti okezone.com yang dapat dilihat berikut ini:

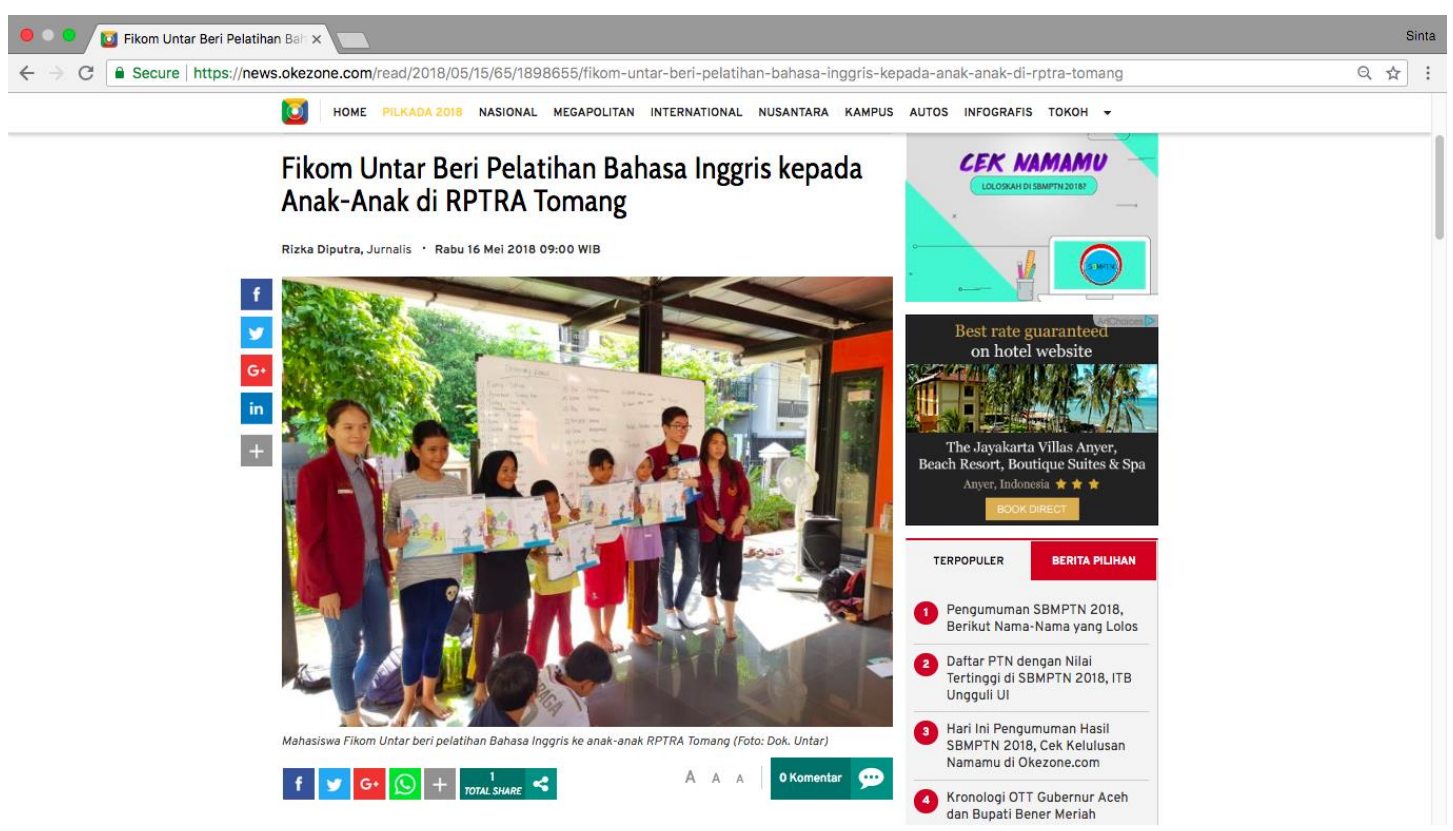

Gambar 5. Kegiatan PKM Fikom Untar yang Terpublikasi di Media (Sumber: data pribadi) 


\section{KESIMPULAN DAN UCAPAN TERIMAKASIH}

Kesimpulan utama yang dapat diperoleh dalam kegiatan PKM ini adalah seluruh kegiatan berjalan dengan lancar dan sukses. Tema tentang pelatihan bahasa Inggris sesuai untuk pengembangan RPTRA Mandala. Selain itu interaksi yang terjadi selama kegiatan belajar anatara tim PKM Fikom Untar dengan anak-anak di RPTRA Mandala berjalan dengan baik. Peserta kegiatan PKM atau khalayak sasaran antusias dalam mengikuti kegiatan, hal ini dapat dilihat dengan banyaknya pertanyaan pada sesi diskusi dan tanya jawab dengan menggunakan bahasa Inggris .

\subsection{Ucapan Terimakasih}

Ucapan terima kasih diberikan kepada Direktur Penelitian dan Pengbadian Kepada Masyarakat (DPPM) Universitas Tarumanagara yang telah mendanai penelitian ini. Selanjutnya ucapan terimakasih juga diberikan kepada Fakultas Ilmu Komunikasi yang telah memberikan kepercayaan kepada tim PKM Fikom Untar untuk melaksanakan kegiatan PKM di RPTRA Mandala Tomang. Ucapan terimakasih juga diberikan kepada tiga mahasiswa Fikom Untar yaitu Safat, Mirah F, Adrianus, Andar Ditya yang sudah membuat dokumentasi foto dan video serta Aureliya Ramadhani, Ivander Stefanus, dan Defrianto yang telah membantu jalanya acara PKM tersebut. Terakhir ucapan terimakasih juga diberikan kepada kepada seluruh tim PKM Fikom Untar dan pihak-pihak yang telah mendukung PKM ini.

\section{Daftar Pustaka}

Alangkara, Dita. (2017). Bertandang ke Kalijodo dan ruang publik lainnya di Jakarta. Diakses pada 14 Februari 2018, dari:

http://www.bbc.com/indonesia/majalah-39093944

Loisa, R., \& Setyanto, Y. (2016). Penyingkapan Diri Melalui Internet Di Kalangan Remaja (Studi Komunikasi Antar Pribadi). Jurnal Komunikasi, 6(3), 31-43. doi:http://dx.doi.org/10.24912/jk.v6i3.38

Paramita, Sinta. (2017). Wisata Politik Dari Lokalisasi Menjadi Rekreasi Ruang Publik Terpadu Ramah Anak (RPTRA) Kalijodo. Prosiding Prosiding Seminar dan Call For Paper, Fakultas Ilmu Sosial dan Ilmu Politik Universitas Muhammadiyah Sidoarjo. Hal 102-108. Diakses pada 14 Februari 2018. Dari:https://works.bepress.com/sinta-paramita/19/

Sari, Purnama, Wulan. (2018). Media Komunikasi Dalam Pendidikan Bagi Anak Di Paud AsShidiqiyah Desa Cikidang, Lembang, Jawa Barat. Jurnal Bakti Masyarakat Indonesia 1 (1), 69-75. Dari https://journal.untar.ac.id/index.php/baktimas/article/view/1881/1043

Zanargi, Regi. (2016). Analisis Framing Pemberitaan Penertiban Kawasan Prostitusi Kalijodo Menjadi Ruang Hijau Terbuka di Kompas.com. Thesis, UPN "Veteran" Yogyakarta. Diakses pada 14 Februari 2018. Dari:

http://eprints.upnyk.ac.id/7428/

Jakarta Open Data. (2018). Data Jumlah Siswa Putus Sekolah SD Menurut KabKota DKI $\begin{array}{lllll}\text { Jakarta. } & \text { Diakses } & \text { pada } & 14 & \text { Februari }\end{array}$ http://data.jakarta.go.id/dataset/jumlahsiswaputussekolahpadasdmenurutkabkotadkijakarta 